\title{
High Strength Glass-Ceramics Fabricated With Coal Gangue as Main Raw Materials
}

\author{
Chen P* \\ Department of Material Science and Engineering, Shaanxi University of Science and Technology, China \\ *Corresponding author: Chen P, College of Material Science and Engineering, Shaanxi University of Science and Technology, Xi'an, Shaanxi, China (710021) \\ Submission: 海 November 09, 2017 Published: 眥April 13, 2018

\begin{abstract}
High strength glass-ceramics were fabricated with coal gangue as main raw material. The effects of the utilization rate of the coal gangue, mineral additives, mineralization agents, forming process, and sintering process on the properties of the glass-ceramics were studied. The optimal utilization rate of coal gungue is $55 \mathrm{wt} \%$ when the utilization rate of another mineral material bauxite is $35 \mathrm{wt} \%$. The glass-ceramics showed a main crystal phase of mullite. $\mathrm{BaCO}_{3}$ and $\mathrm{MnCO}_{3}$ codoping and cosubstitution as mineralization agents obviously enhanced the properties of the glass-ceramics. The strength of $148.36-156.12 \mathrm{MPa}$, water absorption of $0.17-0.02 \%$, and density of $2.66-2.68 \mathrm{~g} / \mathrm{cm}^{3}$ were achieved for the glass-ceramics. By optimization experiments, reasonable and optimal processing parameters of forming and sintering were also determined.
\end{abstract}

Keywords: Coal cangue; Glass-Ceramics; Process optimization; Mechanics property

\section{Introduction}

Glass-ceramics are attractive materials used in various applications, such as building materials, cooking ceramics, machinable ceramics, bio-ceramics, optical materials, etc $[1,2]$. High strength and lightweight are first requirement for some applications. From a point of raw material, utilizing the industrial solid wastes with high contents of silica and alumina is a main direction of developing the glass-ceramics because of low cost and high product performance.

Since the main constituents of glass-ceramics are $\mathrm{SiO}_{2}, \mathrm{Al}_{2} \mathrm{O}_{3}$, $\mathrm{CaO}$ and/or MgO, many inorganic wastes are potential starting materials. Currently, various wastes have been used, such as, slags, coal ash, incinerator ash, and waste glass, and shell, oil shale ash and phosphorous fertilizer. Coal gangue as a type of industrial solid waste is widely used to produce cement [3], ceramics [4,5], refractory brick [6], zeolite [7], lightweight aggregate [8], and so on. A very large amount of the coal gangue is produced in coal production. The amount produced in china is reached above several million tones, and increases about one millions tones per year. Table 1: The composition of the raw materials (wt \%).
However, the comprehensive utilization rate of the coal gangue is limited. To prevent air and river from pollution and save resource, the efficient management and full utilization of the coal gangue are urgent. The coal gangue has a high alumina content of $\sim 30 \mathrm{wt} \%$ and a high silica content of $\sim 62 \mathrm{wt} \%$, and so is suitable for fabrication of the high strength glass-ceramics. In this work, we report the fabrication and the property of the glass-ceramics with the coal gangue as a main raw material.

\section{Experimental Procedure}

The coal gangue was used as main raw materials. Bauxite was used to increase the alumina content in the glass-ceramics. Clay was used as an adhesive and to improve formability of slurry. In addition, small amounts of steatite and limestone were used as additives; and $\mathrm{BaCO}_{3}, \mathrm{MnCO}_{3}$, and $\mathrm{MgCO}_{3}$ were used as mineralizers. The sodium tripolyphosphate (STPP) and methyl cellulose (CMC) was used as a water reducer to decrease viscosity of the slurry. The chemical composition of the raw materials is listed in Table 1.

\begin{tabular}{|c|c|c|c|c|c|c|c|c|c|}
\hline $\begin{array}{c}\text { Raw } \\
\text { Material }\end{array}$ & $\mathbf{S i O}_{2}$ & $\mathbf{A l}_{2} \mathbf{O}_{\mathbf{3}}$ & $\mathbf{C a O}$ & $\mathbf{M g O}$ & $\mathbf{F e}_{\mathbf{2}} \mathbf{O}_{\mathbf{3}}$ & $\mathbf{T i O}_{\mathbf{2}}$ & $\mathbf{K}_{\mathbf{2}} \mathbf{O}$ & $\begin{array}{c}\mathbf{N a}_{\mathbf{2}} \mathbf{O} \\
\mathbf{I n g i t i o n} \\
\mathbf{L o s s}\end{array}$ \\
\hline Coal gangue & 62.5 & 20.8 & 2.12 & 4.83 & 3.14 & 0.83 & 3.12 & 3.17 & 0.7 \\
\hline bauxite & 7.25 & 76.25 & 1 & 1 & 1.5 & 1.5 & 0 & 0 & 11.5 \\
\hline clay & 41.03 & 37.71 & 2.66 & 0.46 & 0.14 & 0.14 & 0.68 & 0.54 & 14.18 \\
\hline limestone & 1.51 & 0 & 55.28 & 0 & 0 & 0 & 0 & 0 & 43.22 \\
\hline steatite & 62.82 & 1.03 & 2.06 & 31.93 & 0.1 & 0 & 0 & 0 & 2.06 \\
\hline
\end{tabular}


Table 2: The basic prescriptions of samples (wt \%).

\begin{tabular}{|c|c|c|c|c|c|}
\hline No. & $\begin{array}{c}\text { Coal } \\
\text { Gangue }\end{array}$ & Bauxite & Clay & Steatite & Limestone \\
\hline $1^{\#}$ & 60 & 30 & 5 & 3 & 2 \\
\hline $2^{\#}$ & 55 & 35 & 5 & 3 & 2 \\
\hline $3^{\#}$ & 50 & 40 & 5 & 3 & 2 \\
\hline $4^{\#}$ & 45 & 45 & 5 & 3 & 2 \\
\hline $5 \#$ & 40 & 50 & 5 & 3 & 2 \\
\hline
\end{tabular}

Mullite $\left(\mathrm{Al}_{6} \mathrm{Si}_{2} \mathrm{O}_{13}\right)$ generally has high strength and so was designed as main crystal phase. Combine with utilization rate of the coal gangue; the basic prescriptions were designed as listed in Table 2.

Typical processes for fabrication of the glass-ceramics are mentioned below: the raw materials were first mixed according to the designed prescriptions. The mixtures were filtered through 10 mesh, wet-milled at ratio of raw materials: ball: water=1: 2.5: (0.30.5 ) for $15-25 \mathrm{~min}$ and then filtered through 120 mesh (Aparture: $0.045 \mathrm{~mm}$, ASTM). Subsequently, as treated raw materials were dried at $50-70{ }^{\circ} \mathrm{C}$ for $3-5 \mathrm{~h}$, the each of the dried samples with a weight of $\sim 200 \mathrm{~g}$ were taken, and $5 \mathrm{~g}$ STPP and $5 \mathrm{~g} \mathrm{CMC}$ were added into each sample. By further ball-milling with appropriate water for $12 \mathrm{~min}$, the slurry was filtered through 80 mesh (Aparture: $0.180 \mathrm{~mm}, \mathrm{ASTM}$ ). Residue on sieve is $\sim 0.1 \%$. After drying at 50 $70{ }^{\circ} \mathrm{C}$ for $3-5 \mathrm{~h}$, the powder was ground and then filtered through 55 mesh (Aparture: $0.280 \mathrm{~mm}$, ASTM). The obtained fine powders were prilled by spraying water and stirring. The prilled grains were filtered through 20 mesh (Aparture: $0.850 \mathrm{~mm}$, ASTM). The fine grains under the sieve were re-sprayed with water with constant stirring and then processed to shape required for strength measurement. The formed samples were then pressed at 25-35 $\mathrm{MPa}$ and dried at $50-100{ }^{\circ} \mathrm{C}$ for $24 \mathrm{~h}$. The large grains on the sieve were dried at $80^{\circ} \mathrm{C}$ for $4 \mathrm{~h}$. The dried samples and large grains were finally heated at a heating rate of $5-10{ }^{\circ} \mathrm{C} / \mathrm{min}$ to $1290-1430{ }^{\circ} \mathrm{C}$ and calcined for 30-90min.

The structural phase of the glass-ceramics was identified at room temperature using X-Ray diffractometer (XRD, $\mathrm{CuK}_{\alpha 1}$, $\lambda=0.15406 \mathrm{~nm}$, Model No. D/Max-2200PC, Rigaku, Japan). The morphology of the glass-ceramics was analyzed by scanning electron microscopy (SEM, Model No: S-570, Japan). The flexural strength of the glass-ceramics was measured by a strength tester (Model No: 401/3, Germany). The water absorbance $\left(A_{w}\right)$ of the grain glass-ceramics was calculated by following equation:

$$
A_{\mathrm{w}}=\frac{W_{\mathrm{h}}-W_{\mathrm{d}}}{W_{\mathrm{d}}}
$$

Where $\mathrm{W}_{\mathrm{d}}$ is weight of appropriate amount of the grains after dried at $110{ }^{\circ} \mathrm{C}$ for $3 \mathrm{~h}, \mathrm{~W}_{\mathrm{h}}$ is weight of the above dried grains after soaked in water at room temperature for $36 \mathrm{~h}$. The density of the grain glass-ceramics (d) was calculated by equation:

$$
d=\frac{m_{0}}{m_{1}}
$$

Where $\mathrm{m}_{0}$ is mass of the appropriate amount of the grains after drying at $105-110{ }^{\circ} \mathrm{C}$ for $3 \mathrm{~h}, \mathrm{~m}_{1}$ is mass of the grains immersing in water at room temperature.

\section{Results and Discussion}

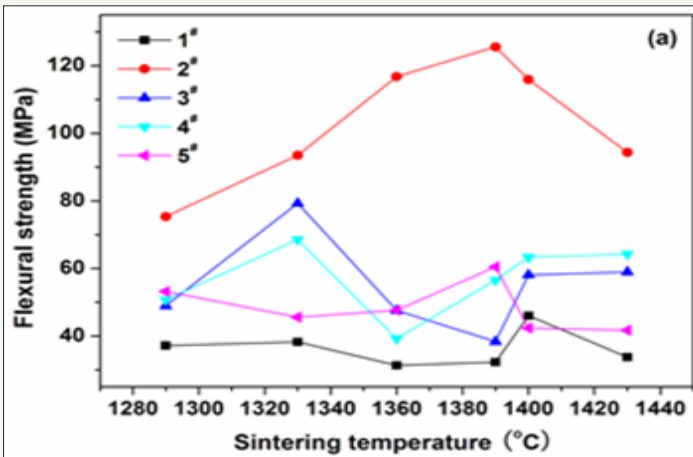

(a)

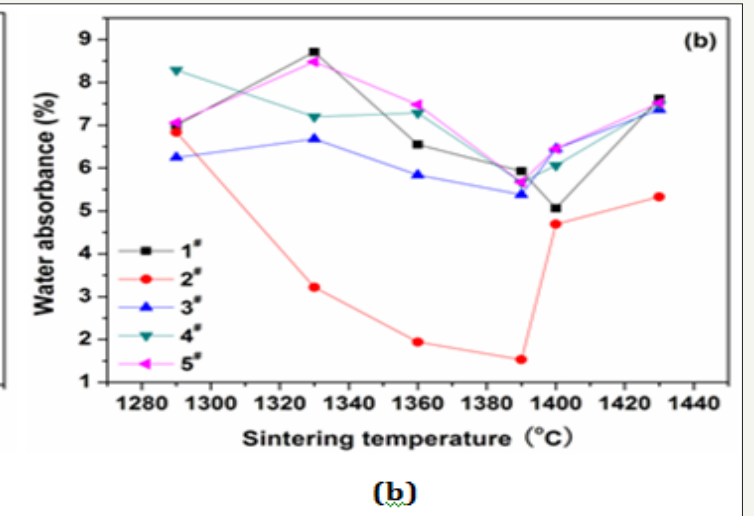

Figure 1: Variations of (a) flexural strength and (b) water absorbance of the glass-ceramics fabricated with basic prescription $1-5^{\sharp}$ with sintering temperature (Sintering time: $30 \mathrm{~min}$; milling time: $20 \mathrm{~min}$; forming pressure: $30 \mathrm{MPa}$ ).

Table 3: The prescriptions of samples containing various mineralizers (wt \%).

\begin{tabular}{|c|c|c|c|c|c|c|c|c|}
\hline No & $\begin{array}{c}\text { Coal } \\
\text { Gangue }\end{array}$ & Bauxite & Clay & Steatite & Limestone & $\mathbf{B a C O}_{3}$ & $\mathbf{M n C O}_{3}$ & $\mathbf{M g C O}_{3}$ \\
\hline $6^{\#}$ & 55 & 35 & 5 & 3 & 2 & 3 & 0 \\
\hline $7^{\#}$ & 55 & 35 & 5 & 3 & 2 & 0 & 3 & 0 \\
\hline $8^{\#}$ & 55 & 35 & 5 & 3 & 2 & 0 & 0 & 3 \\
\hline $9^{\#}$ & 55 & 35 & 5 & 3 & 2 & 3 & 3 & 0 \\
\hline
\end{tabular}




\begin{tabular}{|c|c|c|c|c|c|c|c|c|}
\hline $10^{\#}$ & 55 & 35 & 5 & 3 & 2 & 3 & 0 & 3 \\
\hline $11^{\#}$ & 55 & 35 & 5 & 3 & 2 & 0 & 3 & 3 \\
\hline $12 \#$ & 51 & 33 & 5 & 3 & 2 & 3 & 3 \\
\hline
\end{tabular}

To select reasonable proportion of the coal gangue, five samples with basic prescriptions (Table 2) were first tested. Figure 1 shows variations of strength and water absorbance of glass-ceramics fabricated with different coal gangue contents as a function of sintering temperature. The glass-ceramics fabricated with prescription $2^{\#}$ shown a maximal strength and minimal water absorbance in the sintering temperature range of $1290-1430{ }^{\circ} \mathrm{C}$. Therefore, the prescription $2^{\#}$ was further studied by adding various mineralizers. Table 3 lists the new prescriptions. In which, the prescription $12^{\#}$ was made up by replacing coal gangue and bauxite with BaCO3 and MnCO3. Figure 2-4 illustrate the properties of the glass-ceramics formed at press of $30 \mathrm{MPa}$ and sintered at different temperatures for $30 \mathrm{~min}$. $\mathrm{BaCO}_{3}$ and $\mathrm{MnCO}_{3}$ codoping (prescription $9 \#$ ) leads to better effects with a minimal water absorption $(0.17 \%)$, maximal flexural strength (148.36 MPa) and density (2.66g/ $\mathrm{cm}^{3}$ ). Furthermore, the $\mathrm{BaCO}_{3}$ and $\mathrm{MnCO}_{3}$ cosubstitution leads to an optimal effect. That is, minimal water absorption $(0.02 \%)$, maximal flexural strength $(156.12 \mathrm{MPa})$ and density $\left(2.68 \mathrm{~g} / \mathrm{cm}^{3}\right)$ are achieved. Optimal sintering temperature for these samples is 1360. The chemical compositions of the prescription $9^{\#}$ and $12^{\#}$ are listed in Table 4.

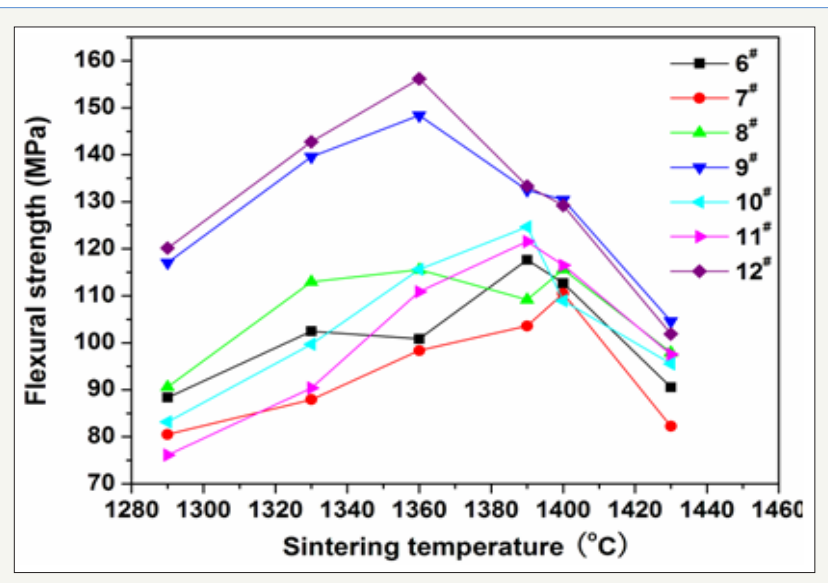

Figure 2: Variations of flexural strength of the glassceramics fabricated with prescription 6-12" with sintering temperature (Sintering time: 30min; milling time: 20min; forming pressure: $30 \mathrm{MPa}$ ).

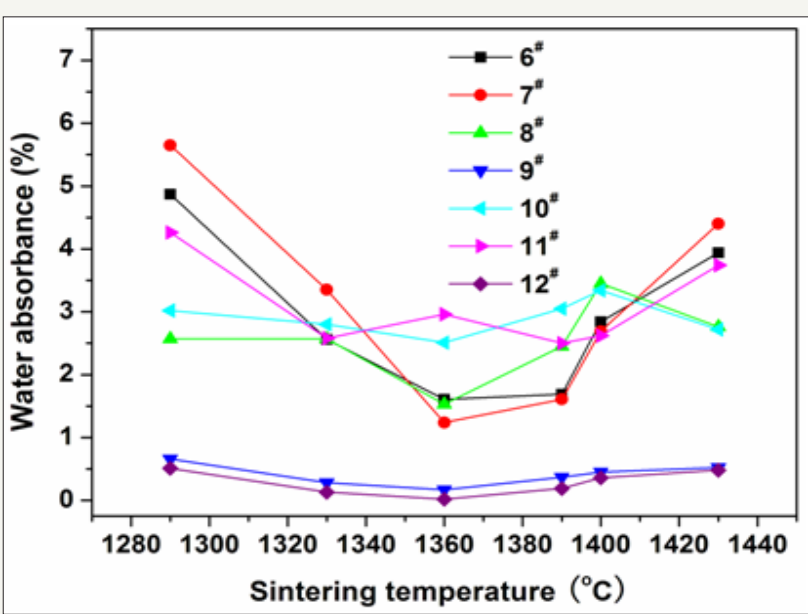

Figure 3: Variations of water absorbance of of the glassceramics fabricated with prescription 6-12" with sintering temperature (Sintering time: 30min; milling time: 20min; forming pressure: $30 \mathrm{MPa}$ ).

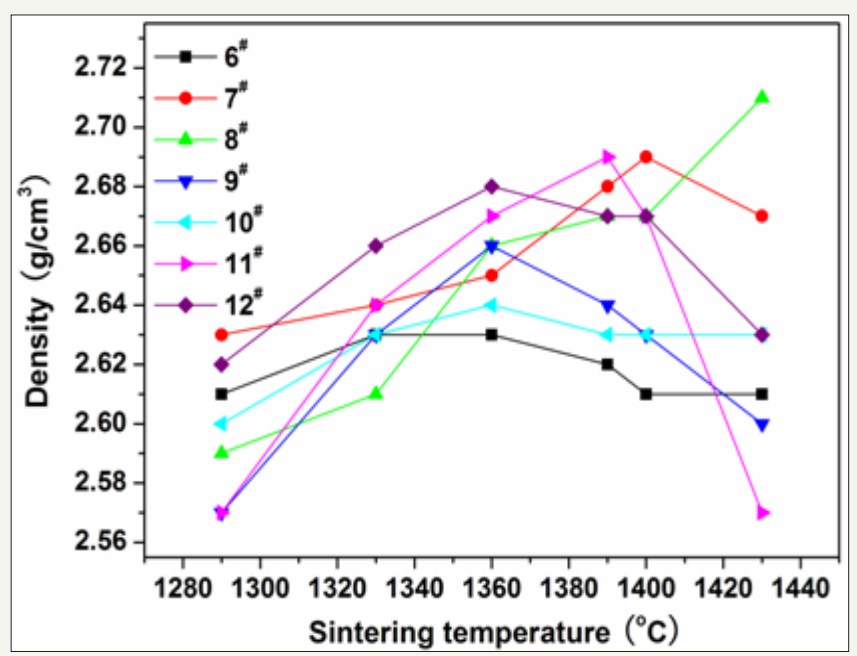

Figure 4: Variations of density of the glass-ceramics fabricated with prescription 6-12\# with sinterimng temperature (Sintering time: 30min; miling time: 20min; forming pressure: $30 \mathrm{MPa}$ ).

Table 4: Chemical composition of the samples (wt \%).

\begin{tabular}{|c|c|c|c|c|c|c|c|c|c|c|}
\hline $\mathbf{N o}$ & $\mathbf{S i O}_{\mathbf{2}}$ & $\mathbf{A l}_{\mathbf{2}} \mathbf{O}_{\mathbf{3}}$ & $\mathbf{C a O}$ & $\mathbf{M g O}$ & $\mathbf{F e}_{\mathbf{2}} \mathbf{O}_{\mathbf{3}}$ & $\mathbf{T i O}_{\mathbf{2}}$ & $\mathbf{K}_{\mathbf{2}} \mathbf{O}$ & $\mathbf{N a}_{\mathbf{2}} \mathbf{O}$ & $\mathbf{M n O}_{\mathbf{2}}$ & $\mathbf{B a O}$ \\
\hline $9^{\#}$ & 33.88 & 53.68 & 2.02 & 1.89 & 0.81 & 0.86 & 0.35 & 0.32 & 3.19 & 2.92 \\
\hline $12^{\#}$ & 33.73 & 54 & 2.03 & 1.76 & 0.71 & 0.81 & 0.25 & 0.21 & 3.38 & 3.1 \\
\hline
\end{tabular}

Figure 5 shows the XRD patterns of the glass-ceramics fabricated with prescription $12^{\#}$. The main crystal phase in the glass-ceramics is identified as mullite $\left(\mathrm{Al}_{6} \mathrm{Si}_{2} \mathrm{O}_{13}\right)$ (JCPDS: 15-0776). Svyatoslavite $\left(\mathrm{CaAl}_{2} \mathrm{Si}_{2} \mathrm{O}_{8}\right.$ ) (JCPDS: 46-1266) as second phase only exist in glass-ceramics sintered at $1290{ }^{\circ} \mathrm{C}$ and $1390{ }^{\circ} \mathrm{C}$. The mullite is generally formed at higher temperature, such as above 1320
${ }^{0} \mathrm{C}$ as reported in previous literature [9]. The formation of mullite in the glass-ceramics at sintering temperature of $1290{ }^{\circ} \mathrm{C}$ may be due to fine raw materials, fluxing actions of minerals additives and mineralizers, and nucleation of $\mathrm{Fe}_{2} \mathrm{O}_{3}$ and $\mathrm{TiO} 2$ existing in the raw materials [10]. The mullite has larger a compressive strength $(0.69$ $\mathrm{GPa}$ ) than many other crystals, such as the forsterite $(0.55 \mathrm{GPa})$, 
the cordierite $(0.32 \mathrm{GPa})$ and boron nitrate $(0.32 \mathrm{GPa})$ [11], and so can providing high strength for the glass-ceramics. Thus, the glassceramics sintered at $1330{ }^{\circ} \mathrm{C}$ and $1360{ }^{\circ} \mathrm{C}$ show better properties. Furthermore, the XRD peaks are enhanced as increase in sintering temperature from $1330{ }^{\circ} \mathrm{C}$ to $1360{ }^{\circ} \mathrm{C}$, and so the glass-ceramics sintered at $1360{ }^{\circ} \mathrm{C}$ shows the optimal properties.

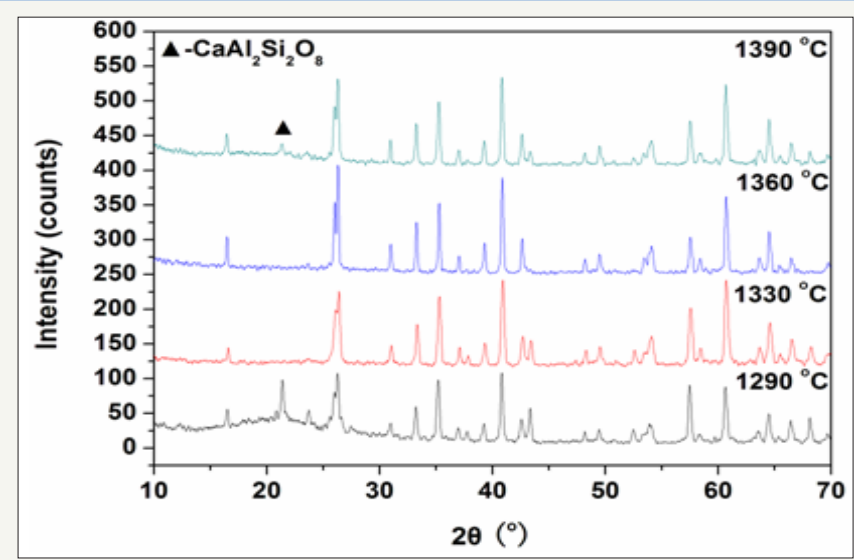

Figure 5: XRD patterns of the glass-ceramics fabricated with prescription $12^{\#}$ at different sintering temperatures for 30min (Miling time: 20min; forming pressure: 30 $\mathrm{MPa})$.

SEM micrographs of the glass-ceramics fabricated with prescription $12^{\#}$ at sintering temperature of $1360{ }^{\circ} \mathrm{C}$ are shown in
Figure 6. The glass-ceramics show small and compact crystals with polygonal morphology.

To optimize processing parameter, the prescription 12\# was further studied in various processing parameters including milling time, forming pressure, and sintering time. The results are showed in Figure 7-9. The increase of milling time from 15 to $20 \mathrm{~min}$ leads to great enhancement of the properties, however further increase of milling time only shows slight effect on the properties. Similarly, the increase of forming pressure from 25 to $30 \mathrm{~min}$ leads to great enhancement of the properties of the glass-ceramics, however further increase of forming pressure only shows slight effect. The increasing sintering time from $30 \mathrm{~min}$ to $90 \mathrm{~min}$ only results in slight increase $(\sim 1.4 \mathrm{MPa})$ of flexural strength and slight decrease $(0.01 \%)$ of water absorbance.

To today, the glass-ceramics prepared with various wasts by many researchers [12-18] generally show a bending strength range of 30-130 MPa [12-16] and the density in the range of $\sim 1.8-3.0 \mathrm{~g} /$ $\mathrm{cm}^{3}[12,13,16-18]$. The type, content, size and density of the crystal phases are the determining factors. Moreover, the glass-ceramics prepared in this work contain relative small amounts of alkali metal and alkali earth metal cations (i.e. $\mathrm{Na}_{2} \mathrm{O}, \mathrm{K}_{2} \mathrm{O}, \mathrm{CaO}$ and $\mathrm{Mg}$ ). This can provide an excellent water-resistance and acid-resistance. Relative high $\mathrm{Al}_{2} \mathrm{O}_{2}$ content can provide a good alkali-resistance. The mullite crystal phase and low porosity (low water absorption) are also in favour of these chemical stabilities.

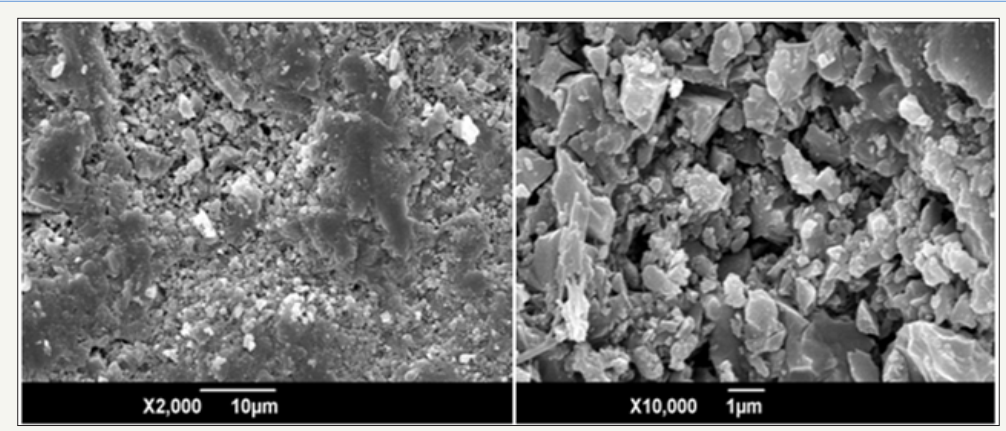

Figure 6: SEM micrographs of the glass-ceramics fabricated with prescription $12^{\#}$ at sintering temperature of $1360^{\circ} \mathrm{C}$ for $30 \mathrm{~min}$ (Milling time: $20 \mathrm{~min}$; forming pressure: $30 \mathrm{MPa}$ ).

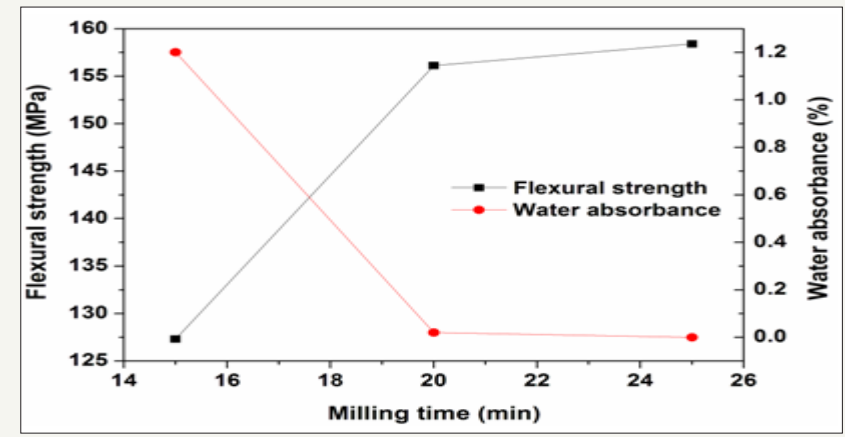

Figure 7: Variations of flexural strength and water absorbance of the glass-ceramics fabricated with prescription $12^{\#}$ at sintering temperature of $1360^{\circ} \mathrm{C}$ for $30 \mathrm{~min}$ with wetmilling time (Forming pressure: $30 \mathrm{MPa}$ ).

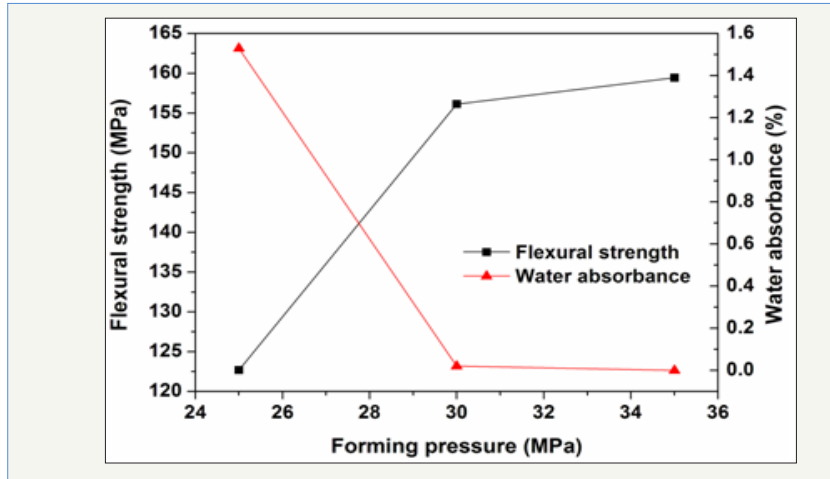

Figure 8: Variations of flexural strength and water absorbance of the glass-ceramics fabricated with prescription $12^{*}$ at sinterimng temperature of $1360{ }^{\circ} \mathrm{C}$ for $30 \mathrm{~min}$ with forming pressure (milling time: 20min). 


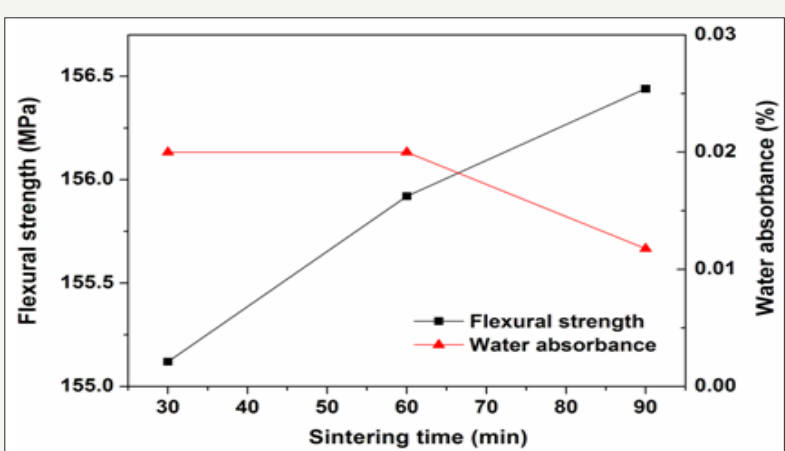

Figure 9: Variations of flexural strength and water absorbance of the glass-ceramics fabricated with prescription $12^{\#}$ at sintering temperature of $1360{ }^{\circ} \mathrm{C}$ with sintering time (Milling time: 20min; forming pressure: $30 \mathrm{MPa}$ ).

\section{Conclusion}

The coal gangue as industrial solid waste has been efficiently used to fabricate glass-ceramics. The effects of utilization rate of the coal gangue, mineral additives, mineralizers, processing parameters of forming and sintering of glass-ceramics are studied. The optimum utilization rate of the coal gangue is determined to be 55 wt \% when appropriate bauxite, clay, limestone, and steatite are used. The appropriate amounts of mineralizers $\mathrm{BaCO}_{3}$, $\mathrm{MnCO}_{3}, \mathrm{MgCO}_{3}$ can improve the property of the glass-ceramics, in which $\mathrm{BaCO}_{3}$ and $\mathrm{MnCO}_{3}$ co-doping and co-substitution show an optimal effects as their amounts are $3 \mathrm{wt} \%$, respectively. The process optimization showed that reasonable forming process parameters are milling time of $20 \mathrm{~min}$ and forming pressure of 30 $\mathrm{MPa}$, while optimal sintering temperature and time are $1360{ }^{\circ} \mathrm{C}$ and $30 \mathrm{~min}$, respectively. Further increases of the milling time, forming pressure and sintering time only lead to slight enhancements of the properties. In these reasonable process parameters, the glass-ceramics were of high strength $(156.12 \mathrm{MPa})$ and low water absorption (0.02\%) and low density $\left(2.68 \mathrm{~g} \mathrm{~cm}^{-3}\right)$, and so may be a promising lightweight and high strength glass-ceramics for various applications including building materials, cooking ceramics and proppant materials.

\section{References}

1. Patridge G (1994) An overview of glass ceramics. Part 1. Development and principal bulk applications. Glass Tech 35(3): 116-126.
2. Pannhorst W (1997) Glass ceramics: State-of-the-art. J Non-Cryst Solids 219: $198-204$

3. Dongxu Li, Xuyan S, Chenchen G, Zhihua P (2006) Research on cementitious behavior and mechanism of pozzolanic cement with coal gangue. Cem Concr Res 36(9): 1752-1759.

4. Mei Y, Zhixing G, Yinsheng D, Xueling X, Kehui Q et al. (2012) Preparation of $\mathrm{CaO}-\mathrm{Al}_{2} \mathrm{O}_{3}-\mathrm{SiO}_{2}$ glass ceramics from coal gangue. Inter J Miner Process 102(103): 112-115.

5. Haipeng Ji, Minghao F, Zhaohui H, Kai C, Youguo Xu, et al. (2013) Effect of $\mathrm{La}_{2} \mathrm{O}_{3}$ additives on the strength and microstructure of mullite ceramics obtained from coal gangue and $\gamma-\mathrm{Al}_{2} \mathrm{O}_{3}$. Ceram Int 39(6): 6841-6846.

6. Ni W, Gong R, Li C (1997) A study of producing light refractory bricks of mullite by using coal gangues as raw materials. 12(4): 79-86.

7. Fang F (1997) Synthesis of zeolite ZSM-35 from coal gangue: Shiloh Xebio. Shiloh Jigging 13(4): 104-107.

8. Jerry GR (1982) Processing and material properties of energy-efficient sintered coal refuse lightweight aggregate, Resources and Conservation. 9: 119-129.

9. Imanaka Y, Aoki S, Camshare N, Nina K (1995) Cristobalite phase formation in glass/ceramic composites. J Am Ceram Soc 78(5): 12651271.

10. He HY (1999) Thermodynamic study of nucleation property of nucleation agent. J Wuhan Univ Technol Mater Sci 14: 28-34.

11. Jones AH, Cutler RA (1980) Light weight proppant for deep gas well stimulation. Terra Tek, USA.

12. Bernardo E, Esposito L, Rambaldi E, Tucci A, Pontikes Y, et al. (2009) Sintered esseneite-wollastonite-plagioclase glass-ceramics from vitrified waste. J Europ Ceram Soc 29(14): 2921-2927.

13. Tomohiro T, Yoshihiro T, Yoshikazu K, Kiyoshi O (2004) Preparation and properties of $\mathrm{CaO}-\mathrm{MgO}-\mathrm{Al}_{2} \mathrm{O}_{3}-\mathrm{SiO}_{2}$ glass-ceramics from kao- lin clay refining waste (Kira) and dolomite. Ceram Int 30(6): 983- 989.

14. Liu HY, Lu HX, Chen DL, Wang HL, Xu HL (2009) Preparation and properties of glass-ceramics derived from blast-furnace slag by a ceramic-sinter-ing process. Ceram Int 35(8): 3181-3184.

15. Bernardo E, Castellan R, Hreglich S (2007) Sintered glass-ceramics from mixtures of wastes Ceram Int 33(1): 27-33.

16. Young JP , Jong H (2002) Vitrification of fly ash from municipal solid waste incinerator. J Hazard Mater 91(1-3): 83-93.

17. Shu DL (2004) Mechanical Property of Enginerring Materials, China Machine Press, Beijing, China, pp. 214-228.

18. Beck WR, Castle RB (1985) Proppant for well fractures and method of making same, US 4493875.
Creative Commons Attribution 4.0 International License

For possible submissions Click Here

\section{Submit Article}

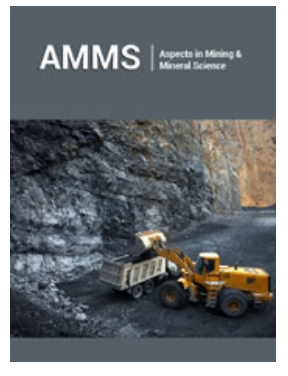

Aspects in Mining \& Mineral Science

\section{Benefits of Publishing with us}

- High-level peer review and editorial services

- Freely accessible online immediately upon publication

- Authors retain the copyright to their work

- Licensing it under a Creative Commons license

- Visibility through different online platforms 